\title{
PENERAPAN CORPORATE SOCIAL RESPONSIBILITY (CSR) TERHADAP PROFITABILITAS PERUSAHAAN (STUDI KASUS PADA PT BANK DANAMON INDONESIA,TBK)
}

\author{
Linda Arisanty Razak \\ lindaarizantyrazak@unismuh.ac.id \\ Muh Aris Pasigai \\ muharispasigai@unismuh.ac.id \\ Husnul Khatimah \\ khusnulkhatimah@gmail.com \\ Fakultas Ekonomi dan Bisnis \\ Universitas Muhammadiyah Makassar
}

\begin{abstract}
This study aims to analyze differences before and after the implementation of a CSR program on profitability carried out by PT. Bank Danamon Indonesia, Tbk. The type of research used in this research is quantitative descriptive research. Data obtained by documentation techniques in the form of financial statements of PT. Bank Danamon Indonesia Tbk before the implementation of CSR in 2002-2009 and after the implementation of CSR in 2010-2017. The calculation technique used in this study is to calculate the percentage of profitability ratios (ROA) of PT. Bank Danamon Indonesia Tbk. While the data analysis techniques used in this study used descriptive statistical tests and tested hypotheses with the Paired Sample T Test analysis method using a tool in the form of SPSS 23. The results showed that there were no differences before and after the implementation of CSR. There is no difference in profitability measured by ROA allegedly because social activities and environmental activities as a form of corporate responsibility for the surrounding environment and social are not good enough so that the impact on the company has not been seen. Besides, the types of banking companies that do not have a direct impact on natural resources also can be one of the factors there is no difference in profitability at PT. Bank Danamon Indonesia Tbk.
\end{abstract}

Key words : Implementation, Corporate Social Responsibility, Profitability

\begin{abstract}
Abstrak
Penelitian ini bertujuan untuk menganalisis perbedaan sebelum dan setelah diterapkannya program CSR terhadap profitabilitas yang dilakukan oleh PT. Bank Danamon Indonesia,Tbk. Jenis penelitian yang digunakan dalam penelitian ini adalah penelitian deskriptif kuantitatif. Data diperoleh dengan teknik dokumentasi yang berupa laporan keuangan PT. Bank Danamon Indonesia Tbk sebelum penerapan CSR tahun 2002-2009 dan sesudah penerapan CSR tahun 2010-2017. Teknik perhitungan yang digunakan dalam penelitian ini yaitu menghitung persentase rasio profitabilitas (ROA) PT. Bank Danamon Indonesia Tbk. Sedangkan teknik analisis data yang digunakan dalam penelitian ini menggunakan uji statistik deskriptif dan menguji hipotesis dengan metode analisis Paired Sample T Test menggunakan alat bantu berupa program SPSS 23. Hasil penelitian menunjukkan bahwa tidak terdapat perbedaan pada saat sebelum dan sesudah penerapan CSR. Tidak terdapatnya perbedaan profitabilitas yang diukur dengan ROA diduga karena kegiatan sosial dan aktivitas lingkungan sebagai wujud tanggung jawab perusahaan terhadap lingkungan dan sosial sekitarnya belum cukup memadai pelaksanaanya sehingga dampaknya bagi perusahaan belum terlihat selain itu, jenis perusahaan perbankan yang tidak berdampak langsung pada sumber daya alam juga dapat menjadi salah satu faktor tidak terdapatnya perbedaan profitabilitas pada PT. Bank Danamon Indonesia Tbk.
\end{abstract}

Kata Kunci: Penerapan, Corporate Social Responsibility, Profitabilitas 


\section{PENDAHULUAN}

Setiap perusahaan sangat erat kaitannya dengan masyarakat sebagai bagian dari lingkungan eksternalnya. Antara perusahaan dan masyarakat harus ada hubungan resiprokal (timbal balik) jika ingin tetap memelihara eksistensinya. keseimbangan hubungan antara Profit yang didapatkan oleh sebuah perusahaan dengan adanya kontribusi secara langsung untuk masyarakat dan lingkungannya merupakan mekanisme check \& balances antara pihak perusahaan dengan pihak masyarakat Dengan kata lain, reputasi suatu perusahaan dapat dilihat dari CSR yang dilakukan. Besarnya suatu CSR perusahaan akan mempengaruhi reputasi perusahaan itu.

Corporate Social Responsibilty adalah suatu peningkatan kualitas kehidupan mempunyai adanya kemampuan manusia sebagai individu anggota masyarakat untuk merespon keadaan sosial yang ada dan dapat dinikmati, memanfaatkan, serta menjaga lingkungan hidup.

Kendala-kendala terkait penerapan CSR di Indonesia diharapkan dapat berkurang dan memperlihatkan perkembangan yang baik setelah diberlakukannya UU No.40 Tahun 2007, dalam undang-undang tersebut dijelaskan bahwa perusahaan-perusahaan yang menjalankan kegiatan usahanya dan atau berkaitan dengan sumber daya alam diwajibkan melakukan tanggung jawab sosial. Dengan demikian terdapat jenisjenis usaha tertentu yang melakukan kegiatan CSR bukan sebagai kegiatan yang sifatnya sukarela tetapi sebagai sebuah kewajiban, oleh karena itu pengungkapan CSR pada jenis perusahaan seperti ini cenderung akan mempengaruhi beberapa elemen perusahaan termasuk didalamnya pertimbangan dari investor sehingga dapat dipastikan akan mempengaruhi kinerja keuangan perusahaan. Namun di sisi lain, ada beberapa jenis perusahaan seperti bank, perusahaan asuransi, dan lain-lain yang tidak diwajibkan melaporkan CSR, untuk jenis perusahaan seperti ini, masih sulit diprediksi apakah pengungkapan CSR akan mempengaruhi profitabilitas atau tidak (Winardi, W., : 2013).

Penelitian ini mengambil objek penelitian PT. Bank Danamon Indonesia Tbk. PT. Bank Danamon Indonesia Tbk mengungkapkan program Corporate Social Responsibility (CSR) pada laporan keberlanjutan (Sustanbility Report) sejak tahun 2010."

Adapun bentuk tanggung jawab sosial Bank Danamon antara lain : dalam bidang keselamatan kerja, kesehatan, ketenagakerjaan, sosial kemasyarakatan, serta di bidang lingkungan hidup. Lewat CSR, dalam menjalankan bisnis, PT. Bank Danamon Indonesia Tbk. berusaha menjadikan suasana kegiatan usaha yang ramah lingkungan dan harmonis dengan masyarakat luas. Dengan demikian, di bidang lingkungan hidup, PT. Bank Danamon Indonesia Tbk melakukan kegiatan CSR melalui Program Pasar Sejahtera.

Berdasarkan uraian diatas penulis ingin mengetahui bagaimana perusahaan di dalam memperoleh profit sebelum diterapkannya CSR dengan sesudah diterapkannya CSR. Apakah terdapat perbedaan profitabilitas sebelum dengan setelah penerapan CSR. Rasio profitabilitas dalam penelitian ini diukur menggunakan rumus ROA (Return on Assets), dengan demikian penulis melakukan penilitian ini dengan judul : "Penerapan Corporate Social Responsibility (CSR) Terhadap Profitabilitas Perusahaan" (Studi Kasus Pada PT Bank Danamon Indonesia,Tbk.) 


\section{TINJAUAN PUSTAKA}

\section{a. Teori Stakeholder}

Konsep tentang Corporate Social Responsibility perusahaan sudah mulai dikenal sejak tahun 1970an dan secara umum dikenal dengan stakeholder theory. Istilah stakeholder diperkenalkan pertama kali oleh Standford Research Institute (SRI) di tahun 1963 (Freeman:1984). Menurut Freeman (1984), stakeholder didefinisikan sebagai sebuah organisasi, grup atau individu yang dapat dipengaruhi dan mempengaruhi tujuan organisasi tersebut. Teori stakeholder menekankan akuntabilitas organisasi jauh melebihi kinerja keuangan atau ekonomi sederhana (Deegan,C et al:2000). Teori ini menyatakan bahwa organisasi akan memilih secara sukarela mengungkapkan informasi tentang kinerja lingkungan, sosial dan intelektual mereka, melebihi dan di atas permintaan wajibnya, untuk memenuhi ekspektasi sesungguhnya atau yang diakui oleh stakeholder.

\section{b. Teori Legitimasi}

Teori Legitimasi merupakan teori lain yang melandasi CSR serta berhubungan erat dengan teori stakeholder. Teori legitimasi menyatakan bahwa organisasi secara berkelanjutan mencari cara untuk menjamin operasi mereka berada dalam batas dan norma yang berlaku di masyarakat. Dalam perspektif teori legitimasi, suatu perusahaan akan secara sukarela melaporkan aktifitasnya jika manajemen menganggap bahwa hal ini adalah yang diharapkan komunitas (Deegan,C:2000).

\section{c. Corporate Social Responsibility (CSR)}

Corporate Social Responsibility (CSR) adalah komitmen berkelanjutan dari suatu bisnis untuk berperilaku etis dan berkontribusi terhadap pembangunan ekonomi sambil meningkatkan kualitas hidup tenaga kerja dan keluarganya serta masyarakat lokal dan masyarakat luas.

\section{d. Profitabilitas}

Merupakan suatu ukuran tertentu yang digunakan oleh entitas untuk mengukur keberhasilan dalam menghasilkan laba. Laba merupakan gambaran mengenai kinerja yang diperoleh dari proses transaksi umum yang dilaksanakan perusahaan selama periode tertentu. Laba dijadikan indikator bagi para stakeholder untuk menilai seberapa jauh kinerja manajemen dalam mengelola suatu perusahaan.

\section{e. Return On Asset (ROA)}

Return on Assets (ROA) adalah salah satu rasio untuk mengukur profitabilitas perusahaan, yakni merupakan perbandingan antara laba bersih sesudah pajak dengan total aset.

$$
\text { ROA }=\frac{\text { Laba bersih setelah pajak }}{\text { Total Aset }}
$$
dapat dinilai apakah perusahaan telah efisien dalam memanfaatkan asetnya dalam kegiatan operasional perusahaan. Rasio ini juga memberikan ukuran yang lebih baik atas profitabilitas perusahaan, karena menunjukkan efektivitas manajemen dalam menggunakan aset untuk memperoleh pendapat. Dan ROA (Return on Assets) digunakan oleh beberapa peneliti sebelumnya sebagai indikator untuk menghitung rasio profitabilitas.

\section{METODE PENELITIAN}

\section{a. Teknik Analisis}

Penelitian ini dapat diklasifikasikan ke dalam jenis penelitian deskriptif dengan pendekatan kuantitatif. Peneliti menggambarkan tingkat penerapan Corporate Social Responsibility (CSR) dan 
profitabilitas pada PT. Bank Danamon Indonesia, tbk. Penelitian ini dilakukan pada PT. Bank Danamon Indonesia, tbk. di bursa efek Indonesia yang diakses melalui www.idx.co.id, waktu penelitian ini sudah dilaksanakan pada bulan juni hingga juli 2019. Populasi dalam penelitian ini adalah laporan keuangan PT Bank Danamon Indonesia,tbk, disusun dalam bentuk tahunan. Sedangkan sampel yang digunakan adalah laporan keuangan yang digunakan sebelum CSR diterapkan secara efektif tahun 2002-2009 dan sesudah CSR diterapkan secara efektif tahun 2010-2017.

\section{b. Teknik Pengumpulan Data}

Teknik pengumpulan data dalam penelitian ini menggunakan teknik dokumentasi, yakni pengumpulan data yang dilakukan pada subjek penelitian melalui dokumen-dokumen laporan keuangan PT. Bank Danamon Indonesia,tbk yang diperoleh dari Bursa Efek Indonesia (BEI) yang diakses melalui www.idx.co.id, serta informasi sustainable report yang berisi tentang tanggung jawab sosial perusahaan PT Bank Danamon Indonesia Tbk, yang diungkapkan dalam website resmi PT. Bank Danamon Indonesia Tbk. dan juga dari sumber atau literatur yang lain yang berkaitan dengan masalah yang diteliti.

\section{c. Teknik Analisis Data}

Profitabilitas dalam penelitian ini menggunakan Return On Asset (ROA). dimana rumus Return On Asset (ROA), yakni :

$$
\begin{aligned}
& \text { ROA } \\
& =\frac{\text { Laba bersih setelah pajak }}{\text { Total Aset }}
\end{aligned}
$$

\section{Uji Statistik Deskriptif}

Uji Statistik deskriptif merupakan uji statistic yang digunakan untuk mengetahui tingkat penerapan tanggung jawab sosial (Corporate Social
Responsibility) dan profitabilitas pada PT Bank Danamon Indonesia Tbk. Adapun pengukuran yang dipakai dalam penelitian ini adalah nilai minimum, nilai maximum, dan mean.

2. Paired Sample T Test

Alat analisis yang dipakai adalah analisis perbandingan rata-rata (Compare Means) dengan menggunakan metode Paired-Sample $T$ Test. Paired Sample $T$ Test merupakan metode analisis yang menguji ada tidaknya perbedaan mean untuk dua sampel bebas (independen) yang berpasangan. Adapun yang dimaksud berpasangan adalah data pada sampel kedua merupakan perubahan atau perbedaan dari data sampel pertama atau dengan kata lain sebuah sampel dengan subjek sama mengalami dua perlakuan.

\section{HASIL DAN PEMBAHASAN}

a. Hasil Penelitian

1. Perbandingan Profitabilitas (ROA) sebelum dan sesudah CSR

Tabel 4.5 Perbandingan Profitabilitas Sebelum dan Sesudah Penerapan CSR PT. Bank Danamon Indonesia Tbk

\begin{tabular}{|c||c||c|c|}
\hline \multicolumn{2}{|c||}{ Profitabilitas Sebelum CSR } & \multicolumn{2}{c|}{ Profitabilitas Sesudah CSR } \\
\hline \hline Tahun & ROA (\%) & Tahun & ROA (\%) \\
\hline 2002 & 2,02 & 2010 & 2,43 \\
\hline 2003 & 2,90 & 2011 & 2,42 \\
\hline \hline 2004 & 4,09 & 2012 & 2,64 \\
\hline 2005 & 2,95 & 2013 & 2,26 \\
\hline 2006 & 1,61 & 2014 & 1,37 \\
\hline 2007 & 2,36 & 2015 & 1,31 \\
\hline 2008 & 1,42 & 2016 & 1,60 \\
\hline \hline 2009 & 1,55 & 2017 & 2,15 \\
\hline Sumber $:$ (data diolah) &
\end{tabular}

\section{Uji Statistik Deskriptif}

$$
\text { Tabel } 4.6
$$

\begin{tabular}{|c|c|c|c|c|}
\hline & $\mathrm{N}$ & Minimum & Maximum & Mean \\
\hline $\begin{array}{l}\text { ROA } \\
\text { sebelumcsr }\end{array}$ & 8 & 1,42 & 4,09 & 2,3625 \\
\hline $\begin{array}{l}\text { ROA } \\
\text { sesudahcsr }\end{array}$ & 8 & 1,31 & 2,64 & 2,0225 \\
\hline $\begin{array}{l}\text { Valid N } \\
\text { (listwise) }\end{array}$ & 8 & & & \\
\hline
\end{tabular}

Statistik Deskriptif Sebelum dan Sesudah Penerapan CSR Descriptive Statistics

Sumber: Hasil Perhitungan Output SPSS 23 
Berdasarkan tabel 4.6 dapat dilihat bahwa nilai minimum untuk profitabilitas sebelum penerapan CSR adalah 1,42 dan sesudah penerapan CSR adalah 1,31. Sedangkan nilai maksimum untuk profitabilitas sebelum penerapan CSR adalah 4,09 dan setelah penerapan CSR adalah 2,64. Nilai rata-rata (mean) profitabilitas sebelum penerapan CSR adalah 2,3625 dan sesudah penerapan CSR adalah 2,0225.

\section{Pengujian Hipotesis}

Pengujian hipotesis dengan menggunakan Uji statistik parametrik menggunakan uji t yaitu paired sample $T$ test, dengan tingkat signifikansi $(\alpha)=0,05$ atau tingkat kepercayaan $95 \%$ yang berarti tingkat kesalahan dari penelitian ini adalah $5 \%$

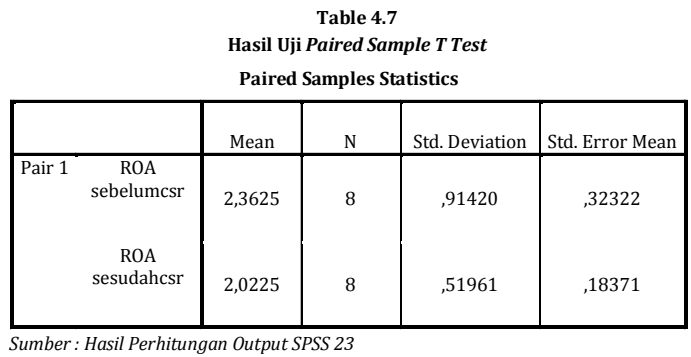

Dari pada tabel 4.7 dapat dilihat bahwasanya rata-rata profitabilitas PT.Bank Danamon Indonesia, Tbk Sebelum penerapan CSR 2,3625 menjadi 2,0225 (rata-rata profitabilitas sesudah penerapan CSR).

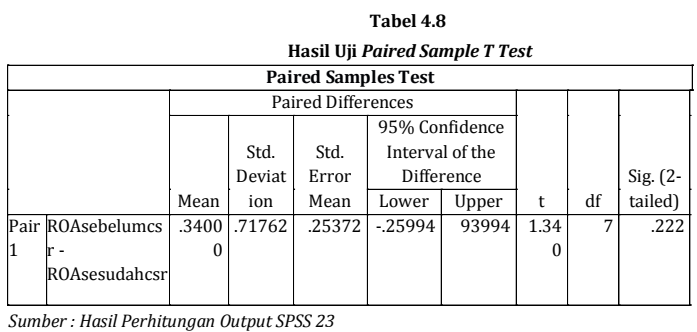

Dari tabel 4.8 Paired Sample T Test dapat dilihat bahwasanya nilai $p$-value untuk uji dua sisi (2-tailed) $=0,222$. Nilai p-value untuk uji dua sisi ini lebih besar dari $\alpha=0,05$, Sehingga H0 gagal untuk ditolak yang berarti tidak terdapat perbedaaan Return On Asset (ROA) antara sebelum penerapan dan sesudah penerapan CSR dikarenakan memiliki nilai sig yang lebih besar dari nilai probabilitasnya, yaitu 0,05.

\section{b. Pembahasan Penelitian}

\section{Perbandingan Profitabilitas Sebelum dan Sesudah CSR}

Berdasarkan Tabel 4.5 diatas dapat dilihat bahwa, Perbandingan Profitabilitas Return on Assets (ROA) PT. Bank Danamon Indonesia Tbk sebelum dan sesudah CSR secara intensif direalisasikan yakni sebelum penerapan CSR dimulai pada tahun 2002 Return on Assets PT. Bank Danamon Indonesia Tbk sebesar 2.02\%, tahun 2003 Meningkat menjadi $2.90 \%$, tahun 2004 meningkat lagi menjadi 4,09\%, tahun 2005 menurun menjadi 2,95\%, tahun 2006 kembali menurun 1,61\%, tahun 2007 meningkat menjadi 2,36\%, tahun 2008 Return on Assets (ROA) PT. Bank Danamon Indonesia adalah sebesar $1.42 \%$ dan pada tahun 2009 meningkat menjadi 1,55\%.

Sesudah Return on Assets (ROA) PT. Bank Danamon Indonesia Tbk setelah CSR secara intensif direalisasikan dimulai tahun 2010 Return on Assets sebesar 2,43 $\%$, tahun 2011 Menurun menjadi 2.42\%, tahun 2012 meningkat menjadi 2,64\%, tahun 2013 menurun menjadi 2,26\%, tahun 2014 menurun menjadi 1,37\%, tahun 2015 menurun lagi menjadi 1,31\%, tahun 2016 Return on Assets (ROA) PT. Bank Danamon Indonesia adalah sebesar 1.60\% dan pada tahun 2017 meningkat sedikit menjadi 2,15\%. Kemudian dari uji statistik deskriptif yang dilakukan terlihat bahwa nilai minimum untuk profitabilitas sebelum penerapan CSR adalah 1,42 dan sesudah penerapan CSR adalah 1,31. Sedangkan nilai maksimum untuk profitabilitas sebelum penerapan CSR 
adalah 4,09 dan sesudah penerapan CSR adalah 2,64. Nilai rata-rata (mean) profitabilitas sebelum penerapan CSR adalah 2,3625 dan sesudah penerapan CSR adalah 2,0225.

Sehingga dapat disimpulkan bahwa profitabilitas PT. Bank Danamon Indonesia Tbk, sesudah penerapan CSR mengalami penurunan dibandingkan sebelum penerapan CSR. Dengan kata lain, sesudah penerapan CSR PT. Bank Danamon Indonesia Tbk tidak lebih mampu dalam memanfaatkan seluruh kekayaannya untuk menghasilkan laba dibandingkan dengan sebelum penerapan CSR.

\section{Hasil Uji Hipotesis Profitabilitas Sebelum dan Sesudah Penerapan CSR}

Berdasarkan hasil Uji Hipotesis Paired Sample T Test memberikan nilai $p$ value untuk uji dua sisi (2-tailed) =0,222 . Nilai $p$-value untuk uji dua sisi ini lebih besar dari $\alpha=0,05$, Sehingga H0 gagal untuk ditolak yang berarti tidak terdapat perbedaaan ROA antara sebelum penerapan CSR dan sesudah penerapan CSR dikarenakan memiliki nilai sig yang lebih besar dari nilai probabilitasnya, yaitu 0,05. Berdasarkan hasil penelitian ini, tidak terdapatnya perbedaan profitabilitas ROA mungkin disebabkan kegiatan sosial dan aktivitas lingkungan sebagai wujud tanggung jawab perusahaan terhadap lingkungan dan sosial disekitarnya belum cukup baik pelaksanaanya sehingga dampaknya bagi perusahaan belum terlihat, atau hal ini mungkin disebabkan dalam pelaksanaan CSR perusahaan, selain itu jenis perusahaan perbankan yang tidak berdampak langsung pada sumber daya alam juga dapat menjadi salah satu faktor tidak terdapatnya perbedaan profitabilitas.
Hasil penelitian ini mendukung penelitian Yustina Herry dan Stefanus (2012) menyatakan bahwa tidak terdapat perbedaan profitabilitas dari sisi ROA dalam industri pertambangan dan farmasi yang terdaftar di Bursa Efek Indonesia. Penelitian ini tidak konsisten dengan hasil penelitian Fauziyatur Rohma (2013) yang menyatakan terdapat perbedaan profitabilitas yang dilihat dari sisi ROA dengan kenaikan yang signifikan antara profitabilitas sebelum dan sesudah penerapan CSR pada PT Bank Danamon Indonesia Tbk. Sedangkan hasil penelitian ini menunjukkan tidak terdapat perbedaan ROA sebelum dan sesudah penerapan CSR.

\section{PENUTUP}

\section{a. Simpulan}

Hasil penelitian yang diperoleh Terkait Penerapan CSR terhadap Profitabilitas Perusahaan pada PT. Bank Danamon Indonesia Tbk, maka dapat dibuat kesimpulan sebagai berikut:

1. Dari hasil uji statistik deskriptif diperoleh bahwasanya profitabilitas yang dilihat dari ROA PT. Bank Danamon Indonesia Tbk, sesudah diterapkannya CSR mengalami penurunan dibandingkan sebelum diterapkannya CSR. Dapat dikatakan, sesudah diterapkannya CSR pada PT. Bank Danamon Indonesia, Tbk tidak lebih mampu dalam memanfaatkan seluruh kekayaannya untuk menghasilkan laba dibandingkan dengan sebelum penerapan CSR.

2. Berdasarkan hasil uji hipotesis diperoleh nilai p-value untuk uji dua sisi $(2$-tailed $)=0,222$. Nilai $p$-value untuk uji dua sisi ini lebih besar dari $\alpha$ $=0,05$, sehingga $\mathrm{HO}$ gagal untuk ditolak. Sehingga dapat diberikan kesimpulan bahwa rata-rata profitabilitas ROA sebelum 
menerapkan CSR dengan profitabilitas ROA sesudah menerapkan CSR Tidak berbeda. Hal ini diduga disebabkan karena kegiatan sosial dan aktivitas lingkungan sebagai wujud tanggung jawab perusahaan terhadap lingkungan dan sosial sekitarnya belum cukup memadai pelaksanaanya sehingga dampaknya bagi perusahaan belum terlihat.

b. Saran

1. Diharapkan agar PT. Bank Danamon Indonesia, Tbk tetap menerapkan CSR dan lebih baik lagi dalam pelaksanaanya sehingga dapat berdampak pada peningkatan kinerja dan laba yang diharapkan.

2. Bagi peneliti selanjutnya dapat melakukan penambahan variabel profitabilitas perusahaan selain dari variabel yang pernah diteliti selanjutnya.

\section{DAFTAR PUSTAKA}

Agus Sartono. 2012. Manajemen Keuangan Teori dan Aplikasi. Edisi 4. BPFE : Yogyakarta.

Deegan, C., 2000. Financial Accounting Theory, McGraw Hill Book Company : Sydney.

Deegan, C., et al. (2000), Firms' Disclosure Reactions to Social Incidents: Australian Evidence, Accounting Forum. Vol. 24 No. 1

Donovan, G., et al. 2000. "Environmental Disclosure in The Corporate Annual Report: $\quad A$ Longitidional Australian Study Paper For Presentation in The 6 th Interdisciplinary Environmental Association Conference". Monteal, Canada

Fahmi, Irham. 2013. Pengantar Manajemen Keuangan Teori dan Soal Jawab. Alfabeta : Bandung
Fatah, K.A., et al. 2016. Pengaruh Pengungkapan Corporate Social Responsibility Terhadap Profitabilitas Perusahaan: Studi Empiris Pada Perusahaan Manufaktur Sektor Industri Dasar dan Kimia yang Terdaftar di Bursa Efek Indonesia. Jurnal Ekonomi dan Bisnis.Vol 10.No 2, diakses 25 Maret 2019

Freeman, R.E., et al. 2001. "A Stakeholder Approach to Strategic Management". SSRN.http://papers.ssm.com/s o13/papers.efm?abstract id=263511.SSRN.Diakses tanggal 1 April 2019

Freeman R. E.1984.Strategic Management : A Stakeholder Approach. Pitman :Boston

Global Reporting Initiative (GRIa). 2013. Pedoman Laporan Berkelanjutan G4:Amsterdam

Gray, R., et al. 1995. Corporate Social and Evironmental Reporting: A Review of The Literatur and A Longitudinal Study of UK Disclosure. Accounting, Auditing and Accountability Journal, Vol 8. No 2 diakses 5 April 2019

Herman, M.O., et al. 2017. Analisis Perbedaan Kinerja Keuangan Antara Sebelum dan Sesudah Berpartisipasi dalam Indonesia Sustanbility Reporting Awards (ISRA). Jurnal Akuntansi dan Manajemen. Vol 12 No 2, diakses 20 Maret 2019

Kasmir. 2015. Analisis Laporan Keuangan. PT Rajagrafindo Persada: Jakarta

Lindawati, A.L., et al. 2015. Corporate Social Responsibility: Implikasi Stakeholder Dan Legitimacy Gap Dalam Peningkatan Kinerja Perusahaan. Jurnal Akuntansi Multipradigma, Vol 6 No 1diakses 7 Juli 2019 
M.Hanafi,Mamduh.2012.Manajemen Keuangan.Edisi Pertama.BPFE :Yogyakarta

Naukoko, S.C., et al. 2016. Pengaruh Perlakuan Strategi Corporate Social Responsibility Dalam Meningkatkan Laba Bersih Pada PT. Bank Mayapada Internasional. Jurnal Riset Ekonomi, Manajemen, Bisnis dan Akuntansi. Vol 4. No 1, diakses 20 Maret 2019

Nor Hadi. 2014. Corporate Social Responsibiliy.Graha Ilmu : Yogyakarta

Peraturan Pemerintah Republik Indonesia No.47 Tahun 2012 tentang Tanggung Jawab Sosial dan Lingkungan Perseroan Terbatas

Peraturan Menteri Negara Badan Usaha Milik Negara No. PER05/MBU/2007 Tahun 2007 tentang Program Bina Lingkungan.

Puspitaningtyas, Z., et al. 2018. Penerapan Corporate Social Responsibility Terhadap Profitabilitas Perusahaan Barang Konsumsi yang Terdaftar di Bursa Efek Indonesia 2012-2016. Jurnal Bisnis dan Manajemen. Vol 2. No 1, diakses 20 Maret 2019

Rohmah, F., 2013. Analisis Penerapan Corporate Social Responsibility (CSR) terhadap Profitabilitas Perusahaan (Studi Kasus PT Hanjaya Mandala Sampoerna Tbk). Jurnal Akuntansi Unesa. Vol 2. No 1, diakses 20 Maret 2019

Rokhlinasari,S., 2016. Teori-teori dalam Pengungkapan Corporate Social Responsibility Perbankan.Jurnal Ekonomi dan Perbankan Syariah. Vol 7 No 1, diakses 21 Maret 019

Rumengan, P., et al. 2017. Pengaruh Corporate Social Responsibility
Terhadap Profitabilitas

Perusahaan Pada PT Bank Central Asia Periode Tahun 2010-2015. Jurnal Riset Ekonomi, Manajemen, Bisnis dan Akuntansi. Vol 5. No 1,diakses 21 Maret 2019

Rusdianto, Ujang. 2013. CSR Communications A Framework for PR Practitioners. Graha Ilmu : Yogyakarta

Santoso, Y., et al. 2012. Perbandingan Profitabilitas Perusahaan Sebelum dan Setelah Penerapan UU No. 40/ 2007 Tentang Kewajiban Perseroan Terbatas. Jurnal Akuntansi dan Manajemen. Vol 13. No.1, diakses 20 maret 2019

Sixtia, A.A., et al. 2018. Analisis Perbedaan Profitabilitas Sebelum dan Sesudah Memenangkan Top CSR (Corporate Social Responsibility). Jurnal Akuntansi \& Manajemen. Vol 13. No 1,diakses 20 Maret 2019

Sudaryanti, D., et al. 2017. Pengaruh Pengungkapan CSR Terhadap Kinerja Keuangan Perusahaan. Jurnal Penelitian Teori \& Terapan Akuntansi . Vol 2. No 1, diakses 19 Maret 2019

Theodorus, B., et al. 2016. Analisis Penerapan Corporate Social Responsibility Terhadap Profitabilitas Pada Pt Bank Central Asia, Tbk. Jurnal Berkala Ilmiah Efisiensi. Vol 16. No 4, diakses 19 Maret 2019

Undang-Undang No. 40 Tahun 2007 tentang Perseroan Terbatas

Undang-Undang No. 32 Tahun 2009 tentang Perlindungan dan Pengelolaan Lingkungan Hidup

Wahyuningtyas, I., 2015. Analisis Pengaruh Pengungkapan Corporate Social Responsibility (CSR) Terhadap Perbedaan Profitabilitas Perusahaan 
(Studi pada PT Timah Persero Tbk). Jurnal Akuntansi Unesa. Vol 3. No 1, diakses 19 Maret 2019

Winardi, W., 2013. Pengaruh Pengungkapan CSR Terhadap Kinerja Keuangan Bank yang Terdaftar di Bursa Efek Indonesia. Jurnal Akuntansi Unesa. Vol. 1 No. 3 www.globalreporting.org

www.idx.co.id

www.danamon.co.id 